\title{
THE LANGUAGE SHIFTING IN MUNA LANGUAGE (A Study of Munanese at Pondidaha Sub-District)
}

\author{
WA ODE FITRI YULIANTY BAY
}

\begin{abstract}
This research discusses the language shifting in Muna language for Munanese who lived in Ahuawatu village, Pondidaha Sub-District, Konawe Regency. Language contact that has occurred at multilingual society in Ahuawatu became an interesting phenomenon to be learnt, because it has close relationship with the use of ethnic language of the residents in this village. This study focuses on the condition of language shifting of Muna language to Java language, and the causes that lead the shift of language for Munanese. The main data of the research was taken in Ahuawatu village. Observation and interview were used by the researcher in collecting the data from five informants in this area. The result of this research showed the condition of Muna language in Ahuawatu has begun to shift for parental age, and dominantly shifted for their children. It indicated from their habits which use Java language step by step in their daily life as a Munanese. The causes of language shift in parental age are the power of Java language, the number of speaker, and intercultural marriage. While the shift of Muna language to their children are caused by the use of Muna language in family domain, also the maintaining process of Muna culture in family domain.
\end{abstract}

Keywords: Language shift, Munanese, Muna Language, Java Language.

\section{Introduction}

Indonesia is a large nation with much diversity. Because of these diversities, Indonesia is very popular in the world. From Sabang to Merauke, there are so many cultures, religions, tribes, languages, and the others as the symbol for every single place. Language is one of some diversity in Indonesia which becomes an interesting object to be learnt.

There are many languages in Indonesia. According to Lewis et.al (2016), there are 719 vernaculars in Indonesia, from Sabang to Merauke. Each area has own vernacular, and every vernacular has a particular form and structure which make them different from another.

Many people in Indonesia use some vernaculars in their daily life. Vernacular can be a communication tool in society. People use vernacular as the secret language when they want to talk about special thing in a community. Every day they use their vernacular in communicating with another people. Some of them try to maintain their ethnic language, but some of them cannot maintain it. Consequently, one vernacular can influence the others, and the language shifting also can occur in a particular community.

Language shift is the moving process of one language to another gradually or suddenly (Crystal, 2008). According to Ferguson (1981), language shift is the replacement use of mother tongue status from one language to another language in a speech community regularly. Language shift means that a certain group are surrender in keeping their language and move to another one. When the shift occurs in a community, the members of the community have chosen a new language collectively (Fasold cited in Tolla, 2006).

Language shift often occur for immigrant groups. Out-immigrant or in-immigrant is the possible factors that can force the movement of minority language to majority language in a community (Baker, 1996). It means, if the immigrant group which become the minority in a 
particular community choose the majority language as a vehicle in communication, so the minority language will disappear time by time because the majority language will reduce the function of minority language.

Reflecting to above description, the writer is interested to carry out the investigation of language shifting in migration community, i.e. in Ahuawatu village, Pondidaha Sub District, Konawe Regency.

Based on brief explanation about language shift above, the writer formulates this research through two questions. They are (1) has language shifting occurred in Muna language especially for Munanese around Javanese at Ahuawatu, Pondidaha Sub-District? Also (2) what are the causes that make the language shift or not shift in Muna language especially for Munanese around Javanese at Ahuawatu, Pondidaha Sub-District occur?

\section{Literature Review}

\subsection{Sociolinguistic}

The term of sociolinguistic is derived from sociology and linguistic. Sociology is a study about human behavior, while linguistic is a study about language. A simple definition of sociolinguistic comes from Finch (2003), he says that sociolinguistic is a study about language and society. Thus, sociolinguistic is a study that talks about language in society.

Sociolinguistic is focused on the use of language by the society and their culture which is closely related to another (Trudgill, 2002). In the same manner, Wardhaugh (2006) also says if sociolinguistic is concerned with the relationship between language and society, and the function of language to build a better understanding in communicating to another people. In addition, Chaika in Latiful (2012) also says if sociolinguistic is a study of using a language in a society through interaction. Briefly, sociolinguistic is not discussed about the structure of language, but how the language is used, so it could play its function well.

\subsection{Language Shift}

Language shift is the moving process of one language to another gradually or suddenly (Crystal, 2008). In the same vein, Willey (1996) has same opinion with Crystal that language shift is a gradual or sudden move process from the use of one language to another language, either by an individual or a group.

According to Weinreich (1968), language shift refers to the habitual changing of society in using one language to another language. Similar with Fasold (cited in Anthonissen, 2009), he defines the language shift as the change of language use in a particular community, for example when a group of people starts to use a new language. Besides, Romaine (2002) says that when two languages compete for use in the same domains, so the language shift is unavoidable.

Anthonisen (2009) identifies language shift as a process of change across generation. If elders still speak their traditional language but their grandchildren do not, then language shift has occurred. In the same manner, Appel and Muysken (1987) also agree if language shift may come slowly and go on for several generations. It means language shift occurs step by step, slowly but give the effect surely.

\subsection{Factors that Influence Language Shift}

There are many factors that can influence the language shift. The often factors that come in this case are bilingualism, migration, number of speakers, and intercultural marriage. These factors will be explained more below. 


\subsubsection{Bilingualism}

According to Baleghizadeh (2008), bilingualism is the phenomenon of communication in two languages. Weinrich (1968) also agrees if bilingualism is the practice of using two languages alternatively both writing and speaking.

Bilingualism is the essential indication of language shift. It is also supported by Downes (1998), he considers that bilingualism is a factor which involves in leading the language shift. In the same manner, Fishman (cited in Extra and Verhoeven, 1999) argues if language shift occurs because the interacting of two languages with unequal power, consequently the weaker language will be dislocated with the stronger language. When people become bilingual with imbalanced power for both languages, then their second language will come to replace their first language or mother tongue unconsciously. Thus, bilingualism is one factor that can cause the language shift.

\subsubsection{Migration}

Migration is one factor that can lead the language shift in a community. Richards (2010), he describes that if language shift often occurs when people migrate to another place which has different language with their mother tongue. Apple and Muysken (1987) also agree if language shift is the case that happens for immigrant groups habitually. In the same way, Afreen (2013) explains that the language shift becomes a common phenomenon where a country has migrants from other countries.

The use of language in social life can be caused by migration. When a group of people decide to move from one place to another place, the language phenomenon will happen. They can influence their language each other. People can shift their vernacular to another language, or maybe they will leave it because of migration. Thus, migration can affect the use of language in particular group.

\subsubsection{Number of Speakers}

The speaker number of particular language is a crucial factor in language shift. According to Appel and Muysken (1987), the size of speaker of certain language becomes an important thing to pay attention if it decreases. Adisaputera (2009) also agrees if more decrease the number of speaker in a community, so more potential the language shift occur. A small language population is much more vulnerable to decimation than a larger one (UNESCO, 2003). It means, a small language group will be influenced easier than large group in maintaining their language if they have no effort to maintain it.

\subsubsection{Intercultural Marriage}

Language shift can be caused by intercultural marriage or different ethnic marriage. According to Holmes (2001), intercultural marriage highly leads to language shift. In the same vein, Romaine (1995) also states that the extent of intercultural marriage is a factor that can cause the language shift. If in intercultural marriages the parents and their children cannot use both of languages or cultures in the same power in their life, or they abandon one of them, so it can lead the shift of language or culture (David, 2008). It means, intercultural marriage has an important responsibility in leading the shift of language in community, especially in family domain. 


\subsection{The Effect of Language Shift}

The final effect of language shift is language death. A language shift phenomenon can lead the death of another language in totality, no speakers of the language, or death of the language in a specific community only. Holmes (2001) argues that when all people who speak a language die, the language dies with them. Appel and Muysken (1987) also says that language shift is a bridge toward language death. It means, when the language shift occurs, so the language death will also occur in the community slowly but surely and unconsciously.

In Indonesia, the vernacular shift may cause the lost of mother tongue. It is caused by the number of speaker will reduce day by day. Consequently, the vernacular will be in the endangered situation.

\section{Research Methodology \\ 3.1.Design of the Study}

Descriptive qualitative was used as the study design in this research. It means that, this research is based on the factual phenomenon in the field of the research. This design is used to describe the data based on its characteristic. It is supported by Berg (2007), qualitative research refers to the meaning, concept, definition, characteristic, symbols, and description of things.

\subsection{Object of the Study}

This study has been conducted in Ahuawatu village at Pondidaha Sub district. The researcher focused on migration communities that come from Muna who live around Javanese in this village. There were five speakers of Muna language in this place that has been taken as the informants because they had some typical below to be an informant. There were some conditions that fulfilled by the informants, such as:

1. They are Munanese who lived in Ahuawatu, Pondidaha Sub District.

2. They are capable in using Muna language.

3. Have a time and available to be interviewed.

4. At least 25 years old for every informant.

5. Every informant should have normal speech organ and good mental. (Adapted from La Ino, 2013).

\subsection{Data Source}

For getting the factual and accurate data in this research, the researcher used two data sources. First source was oral language that was used by Munanese in their daily communication formal or informal situation which has been gotten by the researcher in observation. The second source was based on the interview data from the research instrument which has been given by the researcher to the informants.

\subsection{Technique of Data Collection}

The data was collected by using some techniques; they are interview, observation, and recording. In interview, the researcher asked some question to the interviewee that relate to with language shift situation for Munanese in Ahuawatu. Furthermore, the researcher also did an observation to all Munanese in Ahuawatu village. The researcher has observed the informants" condition and their daily activity by visiting their home one by one. Besides, recording also was used by the researcher. It was used to acquire the oral data from the informants during the interview. 


\subsection{Technique of Data Analysis.}

To analyze the data in this research, the researcher used some steps.

a. Transliterated all recorded data into the written form.

b. Identified and selected the data based on the researcher needs.

c. Explained the analysis result about the language shift phenomenon in a community, and classified the causes which lead the language shift in Ahuawatu village, Pondidaha Sub-District.

d. In the last stage, the researcher made a clear conclusion based on the finding data.

\section{Finding of the Research}

\subsection{Language Shift of Munanese in Ahuawatu}

As what already explained in previous section, Ahuawatu is a migration area at Pondidaha Sub District. An area of migration has close relationship with mixed culture and susceptible each other. The large group can influence another group easily, but it cannot work for the small group, and this phenomenon really occurs at Ahuawatu.

As the minority group in this village, Munanese has been influenced by Javanese, especially in their language. It can be seen not only from their accent that changes into Javanese style, but also in the use of their vernacular. Because of their environment, their accent time by time move to Java accent and it changes reflexively. As Mrs. Zangina (30 years) said:

"...saat saya bertemu dengan teman di masjid, balai desa, atau di mana saja, saya selalu berbahasa Indonesia tapi logatnya menjadi ke Jawa-Jawaan..." (Zangina, 20 Februari 2016)

“...when I meet with my friends at mosque, village office or everywhere, I always use Indonesian language but in Java accent..."

From Mrs. Zangina statements" above, we can see if Java language has real impact for Munanese. Although she does not use Java language in communicating with another people, but she starts change her accent to Java style.

Become the minority in migrant area has made Munanese in difficulty to develop their language, because all of Munanese here are living around Javanese. Vice versa, Javanese can enlarge their language easily because they are the majority group in this area. Every day Munanese have to hear Java language in their daily life, so they try to adapt with them, but unluckily it threats their native language, Wamba Wuna. Therefore, like or dislike, Munanese start shift their language step by step and unconsciously. Mr. Basirun (73 years) strongly agrees with that, as his statement:

“...Bahasa Muna di sini tidak berkembang, paling hanya sesama kita orang Muna. Nda menular sama orang di sini, ... malah orang Muna jadi bisa bahasa Jawa, semua karena pengaruh lingkungan..." (Basirun, 25 February 2016)

"... Muna language does not expand here, may be just for us as Munanese. It does not spread to another. Instead, Munanese can speak Java language; it is caused by the environment..."

Based on Mr. Basirun statements ${ }^{\text {ee }}$, we can know that Muna language is very difficult to develop in this area because of their environment. In this case, the environment refers to the number of Javanese that live together with them in this village. They cannot influence 
another group that exists in Ahuawatu, even in fact they are influenced by another group, namely Javanese.

A small language population is easier to decimate than a larger one (UNESCO, 2003). If we want to correlate Mr. Basirun statements" above with the statements from UNESCO, so we can define that Munanese as a small population in Ahuawatu is influenced by Javanese as the largest group absolutely.

Furthermore, as has been discussed before, because of their population in Ahuawatu, Munanese face many hardships to enlarge their vernacular. It can be seen not only in family domain, but also in every single domain in their daily life. They are in difficulty to use their native language as a communication tool in this area, although only in their family.

In family domain, all of Munanese in Ahuawatu do not use Muna language to communicate with another people at home. They usually communicate by Indonesian language. However, for them who marry with Javanese, they also use Java language in interacting with their spouse or their children. Nevertheless, not all of them can speak Javanese fluently, only Mr. Basirun can do it well. Consequently, the most visible impact of this situation is all of their children cannot use Muna language in their interaction, even just for understand the meaning, no one. They only understand and use Indonesian language, also Java language for children who was born from intercultural marriage.

Moreover, Munanese in this village also use Java language when they talk to another Javanese who cannot use Indonesian language in their daily interaction. When they meet with the elder who has difficulty in using Indonesian language in this village, they always try to use Java language to communicate with them. They do it not only because these elders cannot use Indonesian language, but also reflects their respect to them, because usually these elders start their conversation by using Java language. They are forced by the environment automatically, because of their population is very small, so they should follow the majority group, Javanese. Therefore, they want or not, they should use the same language with these elders if they want to build good interaction.

\subsection{The Causes of Language Shift in Ahuawatu}

The shifting of language has occurred for Muna language at Ahuawatu. Step by step the speakers of Muna language start use Java language to communicate with Javanese around them. Although they are not as fluent as Javanese, but the use of Java language is more than they use Muna language in their daily interaction. They more interest to learn Java language than introduce their ethnic language to another, or at least they maintain it. Step by step, domain by domain, they leave Muna language and move to Java language, so they shift their ethnic language to another one unconsciously. The shift not only happens to parental age, but it also happens to their children that become Munanese automatically because of their parents.

The causes of shifting language in parental age consist of the power of Java language, number of speakers, and intercultural marriage. The most powerful ethnic language in Ahuawatu is Java language. All of life sector in this village are controlled by Javanese, so another tribe except Javanese should follow them as the majority. Economy sector, village government, educational side, and religious field are in power of Javanese. For that reason, Java language also becomes more powerful than another language because of their „suku' position in the society itself.

As the smallest group in Ahuawatu, Munanese has been influenced by Javanese successfully. Become the largest group in this village makes Javanese can affect another group easily, especially in their language. Because of their population is too small, Munanese 
in this area should face difficulties in maintaining their ethnic language even less to develop it. They cannot use their language to communicate with another people, because only the same Munanese that can understand their language. Consequently, they must follow a language from the largest group in this place.

Furthermore, five from six Munanese in Ahuawatu are in mixed marriage with Javanese. Unfortunately, in this mixed marriage family, Java language becomes a dominant one in their daily life. In addition, it has bad impact to their children. Their children only understand and use a dominant language, while Muna language which becomes a minor one is ignored by their children totally. Therefore, aware or not, they have leaved their ethnic language slowly but surely.

Then, language shift also happened to Munaneses" children in this village. The use of Muna language and the maintaining process of Muna culture in family domain are two factors that lead this language phenomenon. The intensity of using Muna language at home has a big effect in maintaining this language. Because of their parents are rare in using Muna language, so their children become a Munanese who do not know Muna language. Their children only understand an ethnic language that they usually hear, namely Java language. Hence, their children leave Muna language step by step and focus to Java language. Rarer they use their ethnic language, so more potential this language to be left.

Another way that can be used to maintain a language is still maintain their tradition. Unfortunately, Munanese in Ahuawatu start leave their culture. They leave their tradition one by one because they have contaminated by Javanese in this village. Oral tradition which can help them in keeping a group "s beliefs is never done by them as a Munanese. Most of them never introduce or do their tradition as Munanese to their children. Consequently, their children have never known about Muna culture.

In conclusion, all of causes above have important role in leading the language shift in this village. It not only happens for parental age but also for their children. Also, all causes above are close each other, so they bring a new habit for Munanese in using their ethnic language. They cannot separate each other; when one cause appears, so another cause also appears, and it happens for all Munanese in Ahuawatu. Therefore, they never realize if their culture especially their ethnic language has shifted day by day, slowly but surely.

\section{Conclusion, Suggestion and Teaching Implication 5.1.Conclusion}

After analyzing the results of the research in the previous chapter, the writer concludes that language shift has occurred in Muna language especially for Munanese who lived in Ahuawatu village. This language phenomenon occurred for parental age and their children. For parental age, shifting of Muna language was in process, while for their children it was dominantly shift. Shifting of Muna language occurred because of some causes absolutely. The power of Java language, number of Muna speakers in this village and intercultural marriage are three causes for language shifting in Munanese parental age. While the intensity of using Muna language and Muna culture maintenance in family domain are the crucial causes that lead language shift for Munaneses" children in this village.

\subsection{Suggestion}

Through this research, the writer gives some suggestions to the further research and for the readers;

1. To conduct the same research about language shift, pay attention to the research instrument, because it can help you in conducting the best research. 
2. For everyone who has ethnic language, do not be shy to use it in our daily life, maintain it as hard as we can, because one day our ethnic language can be lost if we have no effort to maintain it.

\subsection{Teaching Implication}

This research has some teaching implication, such as;

1. In teaching sociolinguistic, the result of this research can be used in determining the causes of language shift in a particular community.

2. The result of this research also can be used in teaching CCU especially in appreciating a culture and how the culture should be maintained.

\section{References}

Adisaputera, Abdurrahman. (2009). Potensi Kepunahan Bahasa pada Komunitas Melayu Langkat di Stabat, Kabupaten Langkat, Sumatera Utara. Medan: Universitas Negeri Medan.

Afreen, Nayma. (2013). Factors of Language Shift from Chakma to Bengali: A Study on the Chakma-Speaking People. Bangladesh: BRAC University.

Anthonissen, Christine. (2009). Bilingualism and Language Shift in Western Cape Communities. Stellenbosch Papers in Linguistics PLUS, Vol. 38.

Appel, R and Pieter Muysken. (1987). Language Contact and Bilingualism. London: Edward Arnold. Retrieved December 28, 2015, from https://books.google.co.id/books

Baker, C. (1996). Foundations of Bilingual Education and Bilingualism $3^{\text {rd }}$ Edition. Clavedon, UK: Multilingual Matters.

Baleghizadeh, Sasan. (2008). Societal Bilingualism and Second Language Education. Human Sciences Journal No. 56.

Berg, Brucel. (2007). Qualitative Research Methods for Social Sciences. California: California State University.

Crystal, D. (2008). A Dictionary of Linguistics and Phonetics, $6^{\text {th }}$ edition. Oxford, UK: Blackwell Publishing

David, Maya Khemlani. (2008). Language Choice of Urban Sino-Indians in Kuala Lumpur, Malaysia. Malaysia: University of Malaya. Lewis et.al. (2016). Ethnologue: Languages of the World, Nineteenth edition. Dallas, Texas: SIL International. Online version: http://www.ethnologue.com.

Downes, W. (1998). Language and Society. Cambridge: Cambridge University Press. Retrieved December 28, 2015, from https://books.google.co.id/books

Extra, Guus and Ludo Verhoeven. (1999). Bilingualism and Migration. New York: Mouton de Gruyter. Retrieved January 3, 2016, from https://books.google.co.id/books 
Ferguson, Charles. A. et al. (1981). Language in the USA. New York: Cambridge University Press. Retrieved May 17, 2016, from https://books.google.co.id/books

Finch, G. (2003). Linguistic: A Guide to Understanding Language, $2^{\text {nd }}$ Edition. Hampshire: Palgrave.

Holmes, J. (2001). An Introduction to Sociolinguistics. Edinburgh: Pearson Education. Retrieved December 19, 2015, from https://books.google.co.id/books

Ino, La. (2013). Protobahasa Modebur, Kaera, dan Teiwa Bahasa Kerabat non Austronesia di Pulau Pantar Nusa Tenggara Timur (Doctoral dissertation). Denpasar: Universitas Udayana.

Latiful, Fadli. (2012). A Descriptive Anlysis of Jargon in Housekeeping Division at Cakra Kusuma Hotel. Yogyakarta: Universitas Negeri Yogyakarta.

Richards, J.C. and Richards Schmidt. (2010). Longman Dictionary of Language Teaching and Applied Linguistics, $4^{\text {th }}$ edition. New York: Routledge.

Romaine, Suzanne. (1995). Language in Society: An Introduction to Sociolinguistics. New York: Oxford University Press. Retrieved January 15, 2016, from https://books.google.co.id/

(2002). The Impact of Language Policy on Endangered Languages. International Journal on Multicultural Societies, Volume 4.

Tolla, Achmad. (2006). Pergeseran Bahasa Daerah Akibat Kontak Bahasa Melalui Pembauran (Studi Kasus Masyarakat Transmigran di Luwu Timur, Sulawesi Selatan). Makasar: Universitas Negeri Makasar.

Trudgill, P. (2002). Sociolinguistic Variation and Change. Edinburgh: Edinburgh University Press.

UNESCO. (2003). Language Vitality and Endangerment. Retrieved December 20, 2015, from www.unesco.org/culture/...../00120-EN.pd

Wardhaugh, Ronald. (2006). An Introduction to Sociolinguistics Fifth Edition. USA: Blackwell Publishing.

Weinrich, U. (1968). Languages in Contact: Finding and Problem. Amsterdam: John Benjamin Publishing Company. Retrieved December 28, 2015, from https://books.google.co.id/

Wiley, T. G. Language Planning and Policy. New York: Cambridge University Press. Retrieved May 20, 2016, from https://books.google.co.id/ 
